\title{
Flashes de estética comparada: lendo imagens cabo-verdianas
}

\author{
Simone Caputo Gomes \\ (Universidade de São Paulo)
}

\section{RESUMO}

O ensaio apresenta, na linha teórica da Estética Comparada, uma galeria de textos e telas cabo-verdianos a serem lidos na relação entre literatura e pintura, de modo a dar a ver como as óticas masculina e feminina recortam imagens de mulher e seus cotidianos. Os escritores Fátima Bettencourt, Manuel Lopes, Maria Margarida Mascarenhas, Oswaldo Osório, Vasco Martins, Vera Duarte dialogarão entre si e com os pintores Armando do Rosário, Kiki Lima, Misá, Sandro Brito, Tchalê Figueira e Tony Barbosa, a partir de visões diversificadas da situação social das mulheres em contexto cabo-verdiano, sob a inspiração ou contestação da Vênus canônica de Botticelli.

PALAVRAS-CHAVE: Estética Comparada, literatura, pintura

\section{ABSTRACT}

The essay presents, according to the theoretical line of Comparative Aesthetics, a gallery of paintings and texts Cape Verdeans to be read on the relationship between literature and painting, so to demonstrate how the optical male and female silhouetted images of women and their daily lives. Writers Fátima Bettencourt, Manuel Lopes, Maria Margarida Mascarenhas, Oswaldo Osório, Vasco Martins, Vera Duarte will dialogue among themselves and with the painters of Armando do Rosário, Kiki Lima, Misá, Sandro Brito, Tchalê Figueira and Tony Barbosa, from diverse visions of social situation of the social context of women in Cape Verde, under the inspiration or challenge to the canonical Botticelli Venus.

KEYWORDS: Comparative Aesthetics, literature, painting 
"Toda imagem incorpora uma forma de ver." John Berger

A proposta que aqui apresento, de ler imagens cabo-verdianas na relação entre literatura e pintura, ancora-se na corrente denominada por Étienne Souriau de Estética Comparada, que supõe a ência entre artes. A tradição comparativa entre as artes remonta à antiguidade, desde a noção de poesia ecfrástica formulada por Simônides, e atualmente alarga sua perspectiva para uma linha de pesquisa denominada "cultura visual", que se desenvolve como uma abordagem dos estudos culturais a partir da relação entre discurso e visibilidade.

Procurando salvaguardar a singularidade das artes a enfocar, entendo, porém, como Thomas Mitchell (1974), que todos os meios de comunicação são meios mistos e todas as representações, heterogêneas, não existindo, se parto do pressuposto de que a atualidade é regida por um paradigma visual, nenhuma arte "puramente" visual nem puramente verbal (MITCHELL, 1974, p. 5).

Outra linha que penso deva ser considerada, subjacente ao trabalho comparativo entre texto e imagem ou entre as imagens textuais e as imagens plásticas, consiste na busca do observador implícito nas estratégias de exposição textual e de leitura visual. As consequências históricas de novas condições representativas revelam-se, na inscrição do observador, como transformações na experiência fenomenológica do mundo, isto é, mudanças na relação entre subjetividade, experiência e realidade. ponto de vista ressalta, dessa abordagem, como categoria precípua para o trabalho com as imagens, considerando, com John Berger, que "toda imagem incorpora uma forma de ver. Mesmo uma fotografia." (BERGER, 1999, p. 12).

Afirmando que "ver precede as palavras" (BERGER, 1999, p. 9), Berger acrescenta que "nunca olhamos para uma coisa apenas; estamos sempre olhando para a relação entre as coisas e nós mesmos" (BERGER, 1999, p. 11), refletindo o modo como estamos situados e supondo um recorte ou seleção de uma cena entre uma infinidade possível. Ver admite ainda, segundo o teórico, uma reciprocidade: ver um morro ao longe supõe que daquele morro podemos ser vistos.

Contudo, a leitura da imagem como obra de arte presume toda uma série de premissas aprendidas sobre Beleza, Verdade, Gênio, Civilização, Forma, Status, Gosto (BERGER, 1999, p. 13), que afetarão o modo de ver. O advento de certas categorias como a "perspectiva" renascentista, por exemplo, causa alterações no modo de olhar as imagens: por seu caráter de "centralizar tudo no olho de quem vê [...], a perspectiva torna o olho o único centro do mundo" (BERGER, 1999, p. 18), abolindo autoritariamente até mesmo a reciprocidade visual, básica ao ato de ver.

Em rumo oposto, o aparecimento da câmera e da fotografia mudará a maneira como o homem via sob a centralização da noção de perspectiva, individualizando as aparições momentâneas e desconstruindo a ideia firmada pela pintura de que as imagens viveriam na atemporalidade (BERGER, 1999, p. 20). O que se vê é, portanto, sempre relativo, depende do tempo e do espaço onde se situa o espectador. Além disto, a câmera faz com que as imagens cheguem até o receptor (ao contrário da pintura, que exige que o receptor vá à tela), democratiza o que antes era restrito 
apenas a uma minoria culta. Assim, os modernos meios de reprodução (BENJAMIN, 1970) tornam as imagens efêmeras, ubíquas, disponíveis, livres de qualquer guarda; elas entram na corrente principal da vida (BERGER, 1999, p. 34).

Com base nesse aparato teórico, aqui sucintamente exposto, buscarei trabalhar com a cultura cabo-verdiana como um hipertexto ou rede simbólica que funcionará como substrato para que se possa apreender uma memória iconográfica das imagens, concebendo-as, com Alberto Manguel (2001, p. 27), como , e, acrescento, narrativas que geram narrativas, ou seja, comentários ou apreciações críticas a respeito delas, mais do que explicações. Interessa-me ainda verificar de que modo o uso do documento iconográfico como fonte documental, na relação com o texto literário, pode contribuir para melhor compreensão histórica de uma dada sociedade, a cabo-verdiana, em específico.

Tendo em mente ainda que cada obra de arte se expande mediante incontáveis camadas de leituras (MANGUEL, 2001, p. 32) e que cada imagem recobre várias camadas de significados (GÖMBRICH, 1978), correlacionarei textos literários curtos (cenas, retratos) e telas no sentido de dar visibilidade a uma ponta do iceberg que constitui o "museu imaginário"1 cabo-verdiano, isto é, o patrimônio de imagens que recortam o modo de ver - e, neste texto, ver as mulheres - naquele país africano.

Cotejarei, nas linguagens da literatura e da pintura, cenas e retratos do dia-a-dia feminino que me possibilitem operar a hermenêutica do cotidiano das mulheres do arquipélago a partir de um microcorpus de imagens que permita entrever como elas constroem a historicidade de suas vozes e ações. A estratégia utilizada será a construção de uma galeria ou instalação imagética que os artistas cabo-verdianos me ajudarão a expor e com a qual o leitor será convidado a interagir.

No que diz respeito à utilização das fontes visuais na construção do texto literário, julgo necessário que este receptor tenha também em mente que as imagens representam subjetividades e códigos que exigem do pesquisador certos cuidados na sua leitura e compreensão, fazendose conveniente examinar a circularidade entre os campos da História Social, da Literatura e das Artes para interpretar os processos de apropriação de determinadas imagens.

Ao pensar uma nova historiografia cultural para o século $\mathrm{XX}$, por meio da comparação de uma infinidade de imagens criadas pelo homem ao longo de sua história - processo que denominou "tradição artística da humanidade" - Ernst Gombrich (1978) buscou incluir nessa tradição não somente as imagens canonizadas como arte, mas toda sorte de imagens produzidas pelo homem. Para Gombrich, a principal tarefa dos historiadores da arte e da cultura, ao trabalhar com imagens, deve ser o entendimento das várias camadas de significados que elas assumem em diferentes sociedades e em diferentes tempos históricos.

Assim, concebendo a imagem como campo de interlocução entre sistemas, neste caso o literário e o pictórico, tenho pesquisado há algum tempo as representações ou imagens de mulher (Vênus) na cultura caboverdiana, tanto erudita quanto popular, com base nas premissas de Gombrich e na asserção do historiador da arte Chris Witcombe de que as "vênus" são as primeiras imagens humanas de identidade. Para Witcombe, essas representações femininas correspondem a um ideal de beleza pré-histórico prototípico da perpetuidade da espécie, em que o 
artista procurava ressaltar características do campo semântico da fertilidade, acentuando os volumes e os caracteres sexuais da figura feminina, desta forma contribuindo para gerar um cânone fisiológico de mulher.

LeRoy McDermott, em estudo sobre essas Vênus pré-históricas (SelfRepresentation in Upper Paleolithic Female Figurines), documenta a heterogeneidade e a riqueza estilística das representações da figura feminina, percurso que procurarei traçar, de forma análoga, nas séries artísticas cabo-verdianas, mas privilegiando o ponto de vista ou o observador implícito das cena ou retratos. E explico a opção, porque em minha pesquisa, tenho observado alterações significativas de constructo quando o ponto de vista ou observador implícito na representação é homem ou mulher. Adiante veremos.

Uma tônica dos flashes, que considero uma linha de força dos discursos literário e pictórico crioulos, é a representação da vida cotidiana, denominada pela história da arte de "pintura de gênero", que surgiu em oposição ao recorte de quadros mitológicos ou de cenas nobres e remonta ao advento da burguesia e de seu propósito de democratização do acesso às obras de arte, tanto no quesito compra quanto no aspecto temático, ao retratar personagens pobres e sorridentes em cenas consideradas "vulgares".

As representações da vida cotidiana, do mundo do trabalho e dos espaços domésticos tornaram célebre, por exemplo, a pintura holandesa do século XVII, que desenvolveu um estilo sóbrio, realista, comprometido com a descrição de cenas rotineiras, de temas diários, de homens dedicados a ofícios e de mulheres no interior da casa, de festas comunitárias, no campo e na cidade. As imagens caracterizavam-se pela riqueza de detalhes, pela precisão e apuro técnico, numa tentativa de registro fiel do que o olho humano era capaz de captar. A distância dos temas nobres, da exuberância e dos padrões de beleza que orientavam a representação dos corpos na pintura italiana da época associava-se às condições de uma pintura inserida no universo burguês dos Países Baixos, em que a economia monetária se encontrava em desenvolvimento acelerado.

Neste contexto, os padrões de gosto dos burgueses flamengos articulavam-se à realidade do trabalho e do comércio, sem lugar para pompas. A vitória do protestantismo, por sua vez, levava os pintores a se especializarem em ramos da arte que não levantassem objeções religiosas e os retratos, as paisagens e as cenas de gênero surgiram, assim, como alternativas aos artistas que haviam perdido a pintura religiosa como filão de trabalho. Pieter Brueghel (1525-1569), O Velho, por exemplo, irá deter-se nas cenas de gênero da vida camponesa: os aldeões no trabalho e em festejos variados. Johannes Vermeer (1632-1675) produz também obras antológicas, como A Leiteira, Mulher Lendo Diante da Janela, entre outras.

A pintura de gênero (ou "petit genre") nasceu como uma resposta nacionalista da cultura holandesa ao processo de libertação dos Países Baixos da dominação espanhola, o que me autoriza, com base em estudos mais aprofundados que tenho realizado (e que aqui não caberá explanar) também associar este estilo (na pintura e na literatura) às respostas de cabo-verdianidade que os artistas crioulos têm dado à dominação cultural colonial portuguesa-branca-européia. Da pintura de gênero deriva a 
"pintura de interior", de cenas do cotidiano doméstico ocorridas em espaços interiores como salas, quartos, cozinhas, facilmente detectáveis nos retratos ou cenas familiares tanto na série pictórica holandesa, quanto na cabo-verdiana, assim como na série literária crioula.

Assim, na senda da pintura (ou representação) de gênero, como definida acima, proporei uma visita do leitor a uma galeria de textos literários e pictóricos selecionados, para que acompanhe como duas modalidades de arte cabo-verdiana recortam a atuação das mulheres no espaço-tempo das ilhas ao longo da história do arquipélago. 0 deslocamento do espectador-leitor na galeria exposta, intrínseco ao ato de visitar, dar-lhe-á a possibilidade de modificar o espaço percebido, como supõe Michel Serres (1994, p. 64), num processo de interação com as imagens e com a instalação proposta (o percurso imagético por mim sugerido).

Em suma, por meio da interdiscursividade entre texto literário e texto visual e com recurso às técnicas da "pintura de gênero", buscarei dar visibilidade a pontos de vista diversificados na representação do gênero feminino pelas modalidades de arte crioula.

À entrada da instalação por mim proposta, o poema de Vasco Martins já prenuncia a associação entre as artes, frequente na série literária cabo-verdiana de Eugénio Tavares, Manuel Lopes, Baltasar Lopes, Corsino Fortes, Vera Duarte, entre outros:
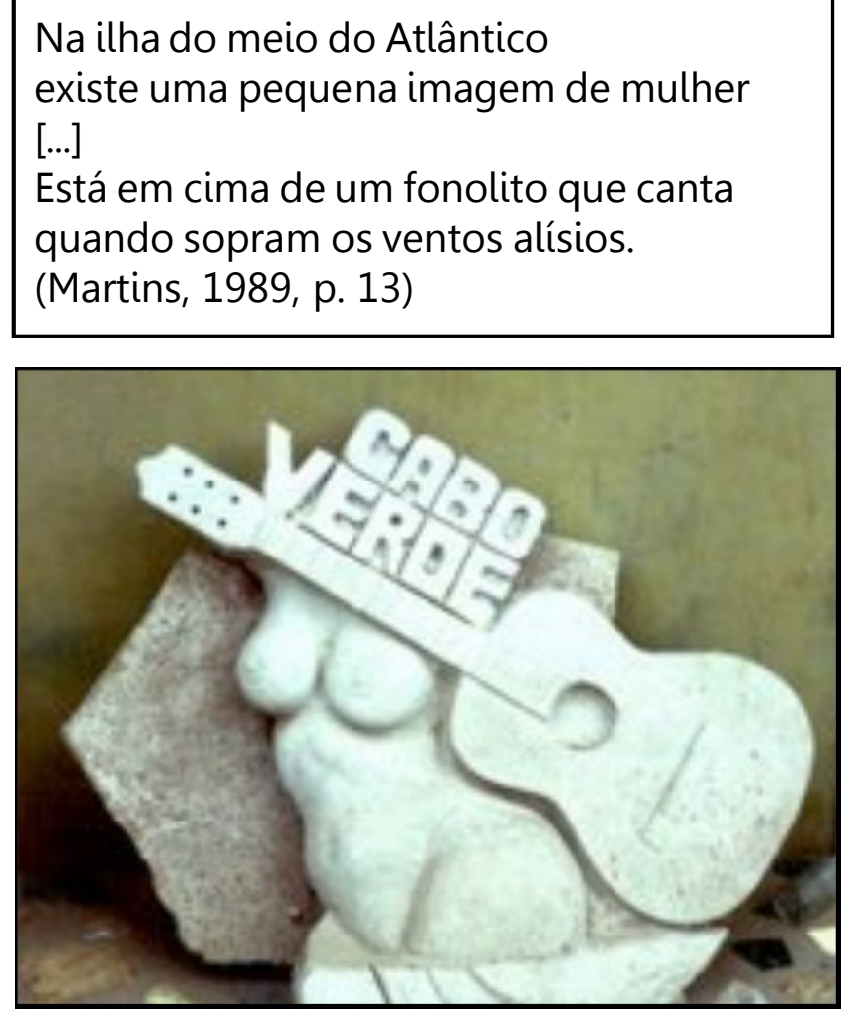

O diálogo do poema de Vasco Martins, escritor e maestro caboverdiano de renome internacional, com a tela de Armando do Rosário (1959, ilha de São Vicente) reforça o mote da fusão entre as artes que perpassa a produção de várias personalidades da cultura crioula. Vejamos. A "ilha no meio do atlântico" representa todo o arquipélago, metaforizado na tela de Rosário pela pedra, um dos ícones mais importantes da configuração física e semi-árida cabo-verdiana; a "pequena imagem de 
mulher" retratada no texto, grande e ilusoriamente tridimensional (semelhando a Vênus de Milo esculturada) no quadro, simboliza a mulher crioula, esculpida em pedra e opulenta em sua fertilidade, pois tem como funções gerar os filhos do país, transmitir a sua cultura e ajudar a construir a sua trajetória.

O "fonolito que canta" e que a mulher encima evoca a música, ao sabor dos "ventos alísios" que sopram em terras cabo-verdianas. Música que nasce, como Vênus, das águas uterinas das mulheres compositoras e cantadeiras das mornas primordiais (cuja evolução admitirá, mais tarde, os instrumentos de cordas, como o violão exposto na tela de Rosário, além do instrumento-voz,) ou das finason do batuque.

Esta mulher imagem, música, escultura, texto será evocada, como o espectador verá adiante, ora pela mulata que executa a dança do batuque (o torno), no primeiro romance de temática cabo-verdiana - $O$ escravo, de José Evaristo d'Almeida (1856) -, ora pela Vênus-morna de Manuel Lopes, no conto "Galo cantou na baía" (1936).

Adentrando a galeria, o leitor poderá ver à sua frente duas telas referentes ao batuque, uma de Kiki Lima (ilha de Santo Antão, 1953) e outra de Tony Barbosa (ilha de Santiago, 1971), que estabelecerão um diálogo com o capítulo principal do romance de José Evaristo d'Almeida:
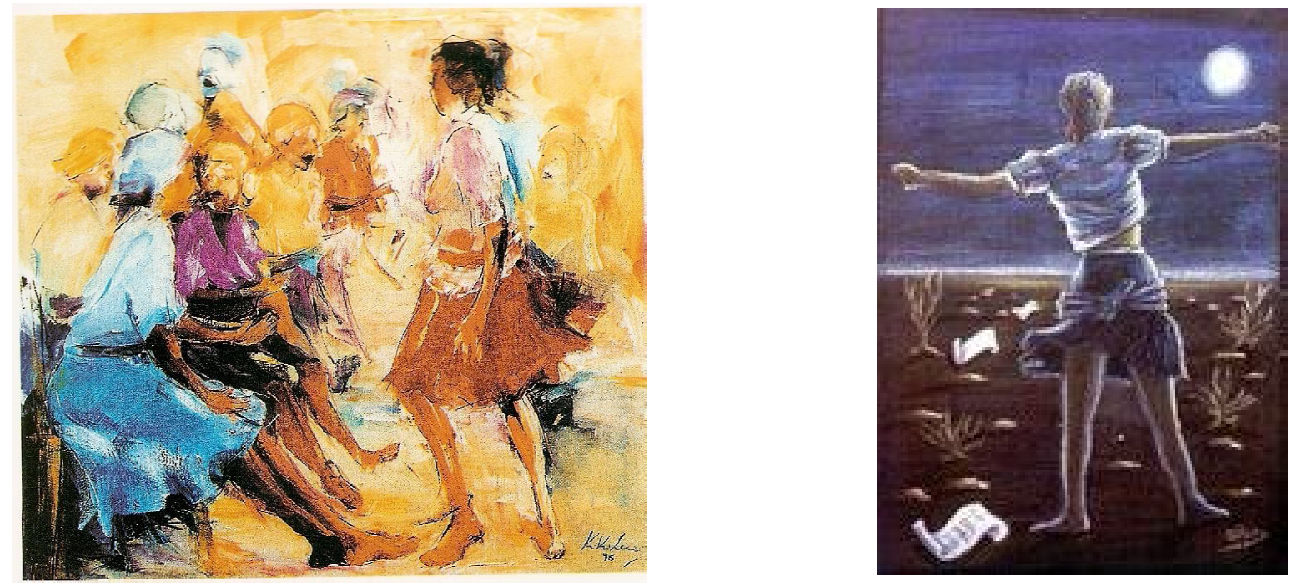

As cenas retratam o cerimonial feminino do batuque cabo-verdiano, mais especificamente no seu auge, quando uma das moças executa o "torno", título do capítulo do romance $O$ escravo. A primeira tela apresenta o grupo de mulheres e a segunda, em close up, a jovem dançarina. Acompanhemos a passagem literária e a interlocução entre as imagens nela expressas e as evocadas nas telas:

Forma-se a roda: trinta ou mais bocas femininas se abrem e dão liberdade às vozes, que elas possuem de uma extensão a causar inveja ao mais abalizado barítono. [...] um outro acompanhamento mais positivo, mais igual e mais conforme ao canto, vinha casar-se a este, de maneira a torná-lo mais alegre - mais estrepitoso - [...] Este acompanhamento compunha-se do bater das mãos sobre os panos, que cada uma passara por sobre as coxas, amarrara junto às curvas, e, com a separação dos joelhos, esticara qual pele em afinado tambor. E esse bater tinha uma cadência toda sua, uma toada para a 
qual não achamos comparação que a explique: em quanto que uma das mãos caía com regularidade extraindo do pano sons e secos, a outra fazia ouvir um tremido, uma espécie de rufo, que é onde está toda a delicadeza do xabeta.

Este alarido convida uma delas a saltar para o centro do círculo, o qual se vai estreitando a ponto, que mal deixa espaço preciso para as evoluções da rainha do momento. Vê-la-eis então medir o compasso com o corpo, cingir o pano à cintura, juntar-lhe aí as pontas em nó, que desata logo, com uma indolência perfeitamente representada. Vê-la-eis - dizemos - torcer-se, requebrarse, impor aos quadris movimentos - demorados no princípio - mas que vão progredindo, exaltando-se à proporção que - de mais em mais - se acelera o compasso do xabeta.

E quando o ente preferido - aquele sobre quem ela emprega os seus olhares - grita com um entusiasmo de possesso ripundá xabeta [...] o xabeta assume um crescendo furioso; e ela - amarrando o pano de maneira a deixar esculpidas as formas do corpo - levando as mãos umas vezes à cintura, outras ao ar, onde faz ouvir os trincos dos seus dedos - olhando alternadamente o céu e a terra - ela se inclina, se dobra, se eleva, se torce, se volta, se arqueia, tudo com agitação febril - com transportes frenéticos - com furor vertiginoso - com movimentos tantos, tão rápidos e lúbricos; que julgareis nela a lascívia personificada! [...]

O xabeta já começara a fazer-se ouvir, e Luiza conservava-se imóvel com os olhos - que ela possuía rasgados, e de uma expressão magnífica - fitos em João. [...] Luiza começara o torno com a languidez e indiferentismo próprio de quem não cura do que está fazendo. [...] Delirando ao excesso da ventura deslumbrada pelas chamas de amor, que acreditou ver relampejar nos olhos do escravo - fechou as pálpebras, e dançou com arrebatamento, delírio e paixão. Oh! mas o que nas outras era lascivo e prosaico, nela tornava-se voluptuoso e poético! (ALMEIDA, 1989, p. 79-80)

Em 1856 publica-se em Portugal a primeira edição do romance $O$ escravo, do português radicado e cabo-verdiano adotivo José Evaristo d'Almeida, considerado por Manuel Ferreira "um dos fundadores da ficção cabo-verdiana"2. Em estilo romântico-realista, a narrativa apresenta as atribulações de um amor camiliano (a escravatura do amor de João pela senhora) condenado pelas barreiras de raça e classe, ao mesmo tempo que documenta a formação de uma sociedade com identidade crioula, prestes a se desembaraçar do sistema escravocrata (a escravatura de condição) e dos seus ranços racialistas. Ilídio Rocha considera que $O$ escravoé "um retrato da vida social dos meados do século XIX" (ROCHA, Apud. VEIGA, 1994, p. 106), o que acrescenta ao texto, para além do valor 
literário, uma importante relevância histórica para os Estudos caboverdianos.

O essencial do enredo do romance decorre no ano de 1835, num cenário próximo de Monteagarro, onde se preparou a malograda insurreição protagonizada por um grupo de escravizados. Os mentores da insurreição pretendiam extinguir definitivamente a sociedade escravocrata, matando os senhores brancos e tomando conta da ilha de Santiago. Denunciados, os cabeças do movimento foram condenados e, depois, mortos, como comprova António Carreira em Cabo Verde Formação e Extinção de uma Sociedade Escravocrata. Esta e outras dissensões sociais, como as ocorridas em Santo Antão, em 1886, expõem as fissuras do período de desagregação da sociedade escravocrata e os tempos de emergência do liberalismo monárquico e, depois, do republicanismo, de clara marca nativista em terras de Cabo Verde.

A intriga urdida por Almeida tece-se de fios da cabo-verdianidade nascente, não somente pelo cenário político, cultural, geográfico e racial em que se insere (a colonização, a língua crioula, os costumes, a flora, a toponímia, o confronto de raças e a mestiçagem), mas também pelos costumes tradicionais afro-negros a que dá visibilidade, sobretudo o batuque, manifestação de resistência na ilha berço da cabo-verdianidade, Santiago, sufocada e silenciada pelo colonizador, mas revitalizada no pósindependência como ritual identitário. Como ressalta Baltasar Lopes em Chiquinho, pela boca do narrador: "Todo mundo gosta da dança do badio, que se entusiasma e mete na festa um batuque [...]. A sala está em África pura, sol na achada e paisagem de savana [...] O badio leva todo mundo consigo na viagem de regresso de séculos" (LOPES, 1986, p. 106).

Assim Luiza, a escrava, entrega-se ao "prazer do batuque" ("uma das poucas distracções concedidas aos escravos") e aos "requebros do torno [...] com um frenesi vertiginoso, com toda a ânsia de um delírio febril" (ALMEIDA, 1989, p. 52). No capítulo "O torno", ela é a protagonista, escrava transformada em rainha pela arte popular, "voluptuosa e poética" (Ibidem, p. 80). Formada a roda de mulheres, como sugere a tela solar de Kiki Lima (figuras femininas em semicírculo, peles e cenário cor de terra e executadas as duas primeiras partes do ritual do batuque - finason ("trinta ou mais bocas femininas se abrem e dão liberdade às vozes") e o xabéta ("o bater das mãos sobre os panos, que cada uma passara por sobre as coxas, amarrara junto às curvas, e, com a separação dos joelhos, esticara qual pele em afinado tambor") - Luiza entra na arena do baile ou terêroe executa o "torno".

A pincelada rítmica de Kiki Lima capta o movimento da cena que perdura desde o nascimento - em luminosidade amarelo-ocre - da cultura cabo-verdiana aos dias de hoje, sendo esse ciclo de tempo simulado pelo contraste da cena solar retratada por Kiki com a paisagem lunar em que Tony Barbosa ambienta o torno. Por outro lado, este insere na tela outras artes, a literária e a musical, representadas pelos papéis e/ ou partituras espalhados pelo solo cabo-verdiano, árido em plantação, mas fértil em cultura.

No texto de José Evaristo d'Almeida, a fala do narrador, colonial e masculina, capta com estranheza o ritual africano e o demonstra na percepção dos sons "pouco harmoniosos", "em completo desacordo", na impossibilidade de comparação entre o que ouve e o mundo já conhecido. 
O espectador privilegiado da performance, escolhido pela dançarina do torno - o escravo João - é percebido pelo narrador como "possesso" e a mulher, como "a lascívia personificada". Malgrado essas arestas de sintonia entre a visão do colonizador português e a manifestação cultural afro-negra, a descrição é uma das mais próximas à realidade da experiência do batuque cabo-verdiano e, apesar de o observador implícito preconceituosamente qualificar a sensualidade feminina como "lasciva", não deixa de colocar em destaque, em proporções gigantes, o protagonismo feminino na cena ritual do batuque.

Domínio das mulheres, o batuque mantém a tradição afro-negra e leva ao êxtase a liberação, por parte dos escravizados na ilha de Santiago, da dureza da labuta diária, como o leitor de imagens poderá observar na tela de Tony Barbosa. Nela, à luz da lua, olhos para o céu e braços abertos em oferta, a moça executa no terreiro a sua dança, em comunhão com o cenário telúrico do solo agreste. Seu êxtase, representado pelo pintor, constitui o auge de um ritual circular que simula o ritmo orgástico da mulher e da terra (finasonlenta/tchabéta/ ripundả thabétal torno/finason lenta).

Ressalto ainda que o finason era, tradicionalmente, entoado por uma mulher mais velha, que transmitia, com sua voz áspera, agreste, e sua arte de improvisação, uma crônica da existência, uma pedagogia social e conselhos morais, por meio da filosofia dos provérbios, de críticas ou recomendações. As cantadeiras de finason, remanescentes dos griots africanos, guardam a memória coletiva e Nhá Nacia Gomi (Inácia Gomes) é sua representante máxima em Cabo Verde. Lembro ainda que o batuque cabo-verdiano acompanhava tradicionalmente os ritos de passagem: as cerimônias do casamento, da tabanka, os ritos oficiais da vida (como o nascimento), as festas dos Santos. Mas, como ressalva Jean-Yves Loude,

[...] até a independência, as autoridades [coloniais] sempre ignoraram essa manifestação de mulheres desavergonhadas, que aquecem até à ebulição os ritmos do Diabo na véspera de um sermão perante Deus. 0 terreiro faz concorrência à igreja [...]. Mas o mais insuportável para a autoridade européia é sentir que a planta africana triunfa através do batuque como uma silva indestrutível (LOUDE, 1999, p. 65).

Resistência e liberação depois de um dia de exploração, violência e trabalho duro, impulso pagão sobrevivente às restrições da igreja católica (que não batizava ou casava praticantes do batuque), tradição negra proscrita em língua proibida (o crioulo), eis a síntese do batuque, provavelmente a forma musical que mais define as raízes cabo-verdianas (GONÇALVES, 2006, p. 16) e que provavelmente se estendeu a várias ilhas no século XIX, preservando-se do tempo dos escravizados até os nossos dias. De música/manifestação "de preto", "não-civilizada" a manifestação identitária, revigorada no pós-independência, eis o ciclo histórico do batuque. Hoje, manifestação mais de palco do que de terreiro, acompanhada de instrumentos eletrônicos (batuque em orquestra) e com as batucadeiras utilizando garrafas de plástico para percussão, o batuque tem assumido variações. Mas, como enfatiza, em refrão, o poeta Corsino 
Fortes, "o batuque não pára/ nas nossas ancas de donzela" (FORTES, 2001, p. 75-79). Continua vivo na arte popular cabo-verdiana.

A partir deste ponto, convido o leitor a se deslocar um pouco mais pelos corredores da galeria e, na próxima sala, destaco o diálogo imediato do conto de Manuel Lopes - "Galo cantou na baía" (1984) - com a tela inicial de Armando do Rosário, que destacava uma imagem de mulher semelhante à da Vênus da ilha grega de Melos ${ }^{4}$ ancorando em suas belas formas (ancas) um violão. O conto de Lopes, por sua vez, alude a obra de Sandro Botticelli para dar relevo a mais uma figura feminina: a Vênusmorna-ilha-mulher cabo-verdiana. O literato cabo-verdiano (que também era pintor e músico) representa no texto o nascimento da morna, modalidade artística que, à semelhança do batuque, reúne, a um só tempo, música, poema e performance (dança):

A última que fez entusiasmou deveras .[...] Foi depois dum baile no Tolentino, na madrugadinha [...] com o vento do mar a bater-lhe na cara e as ondas fosforescentes ali a dois passos rebolando na areia invisível, 'como Vênus na sua luminosa aparição, parte onda parte mulher...ou meia morna'.[...]

Quando sinto que estou para 'ter morna', procuro sombra. E sombra com mar diante. Só com mar diante... A mesma inquietação voltou a formigar-lhe lá dentro, transformada em vagas palavras confusas e em notas de música sem sentido. Esta, não obstante, já revelava um ritmo embalado, de remo na forqueta, mas era, por enquanto, uma melopéia estranha, elementar, quase reminiscente, toada de coisa recordada, sons ainda dúbios em busca de equilíbrio [...].

De súbito estacou. Apurou os ouvidos. Suspenso assim alguns segundos entre a realidade e o sonho, escutou dentro do cérebro um chacoalhar de vozes e ecos. Toi reconheceu o atalho que, habitualmente, o levava aos ocultos tesouros. [...]

A quadra saíra assim inteirinha, de improviso. [...] Vênus nascia completa, com cabeça, tronco e membros, e alma. Declamou, cantarolando, duas, três vezes a quadra recém-nascida das ondas do mar. [...]

Veio mesmo do mar. _Ahn! Cantar de galo, galo canta na baía! Sonha naturalmente que está empuleirado numa árvore que balança com a aragem. [...] Até galo já canta na baía! Mas é poético. Se fosse rouxinol ou cotovia, como nos livros, mais poético seria. Mas não temos cotovias, temos é galo. [...] Qualquer um que o ouve cantar, fica sabendo que a manhã não tarda, o sol vem perto. Toi declama: 'Galo cantâ na baía ...' assim mesmo na língua sabe da nossa terra... [...] A segunda quadra irrompe inteirinha, numa catadupa de palavras e música $[\ldots]$

Era a linha dorsal, o eixo. Era o nascimento de Vênus. Morna salgada, morna de mar. Música e letra se 
Na linha da historiografia cultural proposta por Ernst Gombrich (1978), a imagem do nascimento de Vênus, retomada por Botticelli (1482) de textos neoplatônicos de Marsilio Ficino e poemas de Poliziano, pertence à "tradição artística da humanidade" e, como tal, é alçada pelo ficcionista cabo-verdiano Manuel Lopes, com vigor pictórico, a protagonista de seu conto publicado no segundo número da Revista Claridade, em 1936, que tem como tônica a aproximação das artes (música, literatura e pintura) a partir da capa, a letra da morna "Vénus", de B. Léza (Xavier da Cruz).

Manuel Lopes retoma de Botticelli a releitura neoplatônica do mito de Afrodite-Vênus que emerge do mar (Anadiômene) numa concha levada à praia pelos deuses eólicos. Na versão do artista italiano, em acordo com a do pintor grego Apeles, inspirada por sua vez no relato de Hesíodo na Teogonia, Afrodite-Vênus nasce das espumas (aphros) do mar, que representam a mistura do sêmen e do sangue derramados de Urano (o Céu) ao ser castrado por seu filho Cronos-Saturno, numa disputa de poder. O simbolismo da concha na tela renascentista, além do redondo que se associa à simbólica do feminino, parece evocar as qualidades fecundantes da água e Vênus é considerada, nessa versão, uma deusa genetrix ou da criação.

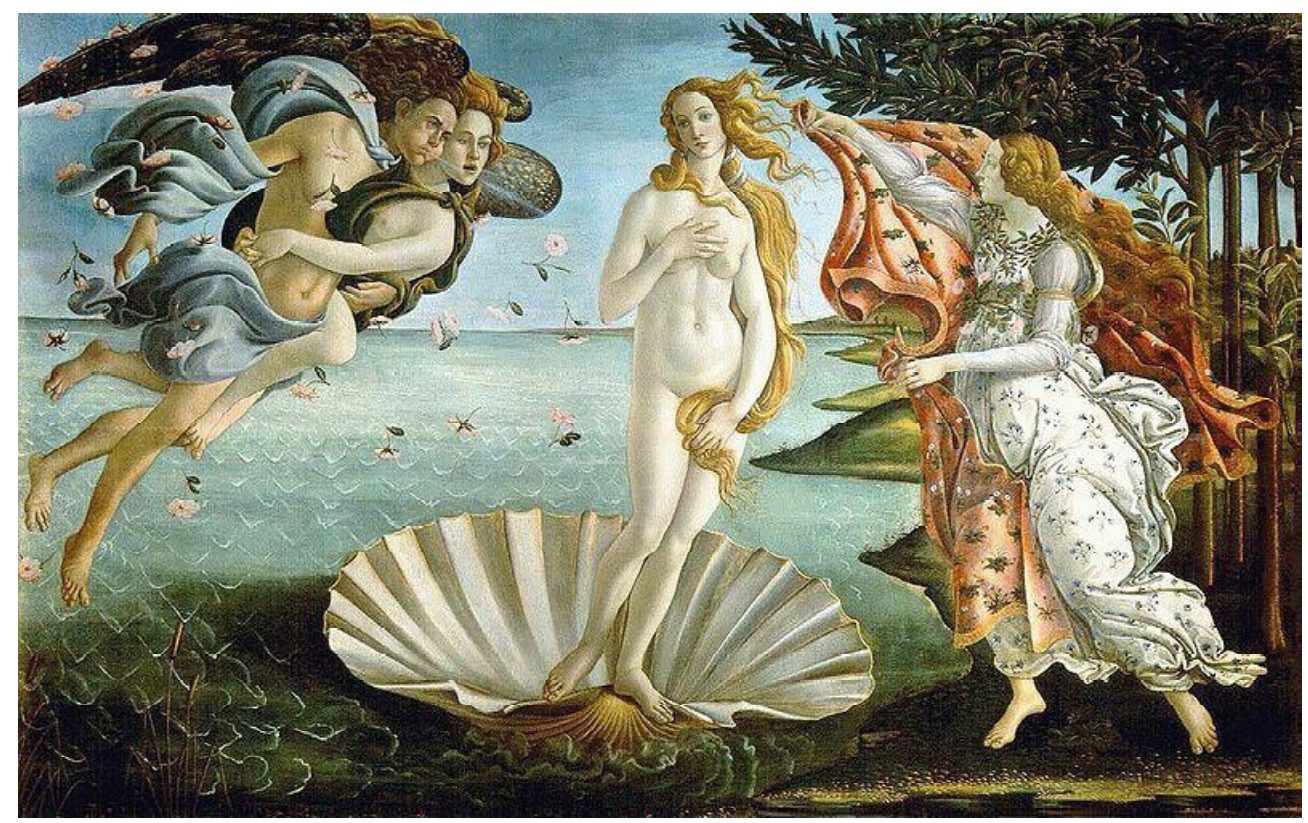

Importante é notar que o lirismo presente na obra de Botticelli se concentra menos na ação da figura feminina e mais na sua exibição, que incita à adoção de uma atitude contemplativa, de admiração estética por parte do observador da tela, o que acaba por tecer a apologia da Beleza feminina estática encarnada na figura de Vênus como representação emblemática da perfeição totalizante. De criadora, Vênus passa a ser vista, sob a égide da canonização masculina de Botticelli e seguidores, como criatura ou coisa criada. Se concebermos esta Vênus como representante da "condição" feminina, ressalta dela uma espécie de autismo estético e, em conseqüência, um impedimento vivencial, que poderá ser associado ao contexto temporal do conto de Manuel Lopes, de dupla submissão 
das mulheres em Cabo Verde: patriarcal e colonial.

$\mathrm{Na}$ versão crioula de Manuel Lopes, os nascimentos da mornamulher e do conto se dão em ambiente marítimo, que pode ser relacionado tanto à insularidade geográfica quanto às atividades econômicas do arquipélago. Lembremos que o culto a Afrodite se espalhou, na Grécia, através de navegadores e pescadores, que a denominavam "Pelágia" (marinheira). Toi, o criador de mornas na narrativa de Lopes, associa-se ao pescador de pérolas (de forma arredondada, como as ilhas de Cabo Verde, e protegidas pelas conchas bivalvas, como a Vênus) numa segunda versão do conto, publicada em 1958 pelo autor:

[...] estava assente que a morna teve sua origem no mar. Como Vênus [...]. 'Digo e torno a dizer a vocês que morna veio do mar. Toada de morna é toada de mar. As minhas têm um pouco de sal, porque é lá no mar onde ela nasce que as vou buscar'. Depois de um transe, Toi teve a nítida sensação de que emergia do fundo, como um pescador de pérola; e começou a cantar em voz alta [...]. A quadra era estupenda! (LOPES, 1959, p.322-323)

Assim como na tela de Botticelli, também no conto de Manuel Lopes a noção de perspectiva coloca a figura da Vênus no centro da cena, pois que o constructo imaginário à época da produção do texto literário, tal qual o renascentista, elege a visão do homem europeu, branco, heterossexual e machista como o verdadeiro protagonista da ação, ou seja, de fora do quadro, este espectador implícito frui o corpo de mulher que para ele se exibe (em imobilidade social) "completo", como a morna de Toi, em "cabeça, tronco e membros, e alma". A função feminina, nessa trilha imaginária de perspectiva masculina, resume-se em incitar ao amor e à reprodução, como o corrobora outra passagem do conto de Manuel Lopes:

[...] a morna veio do mar. Como Vénus (imagem colhida num tal Alcindo que fazia parte dum grupo literário), surgiu pura e nua das espumas do mar, e também como Vénus, é a protectora do amor, porque foi à sua sombra que os nossos avós armaram casamento e o farão também os filhos dos nossos filhos, afirmara Toi, com eloquência, num baile nacional do Tolentino (LOPES, 1959, p. 325).

Comparadas a esta, outras Vênus cabo-verdianas se mostrarão, na literatura e na pintura. Por meio de outros modos de ver, ou com outros observadores implícitos nas imagens expostas. Avance um pouco mais, leitor, na galeria.

O conto "Rebindita", extraído do livro Nimores e Clara \& Amores de Rua (2003), de Oswaldo Osório (1937, ilha de São Vicente), retrata, tendo como cenário o cais do Porto Grande, a estória de uma "menina de vida" (OSÓRIO, 2003, p. 119) que se relaciona com o narradorpersonagem, homem casado, num baile de Carnaval no Éden Park, a mais importante sala de espetáculos da história de Cabo Verde. 
Coloco o trabalho plástico de Tchalê Figueira (1953, São Vicente), "Carnaval um" (acrílico sobre jeans), para dialogar com o texto de Oswaldo Osório, na ambientação do encontro dos amantes. O cotidiano mindelense, em especial o da Rua da Praia, de onde, da perspectiva do seu ateliê, Tchalê Figueira observa a vida que se anima entre tipos populares como prostitutas, vendedores, marinheiros, é uma das linhas desenvolvidas pelo seu trabalho artístico.

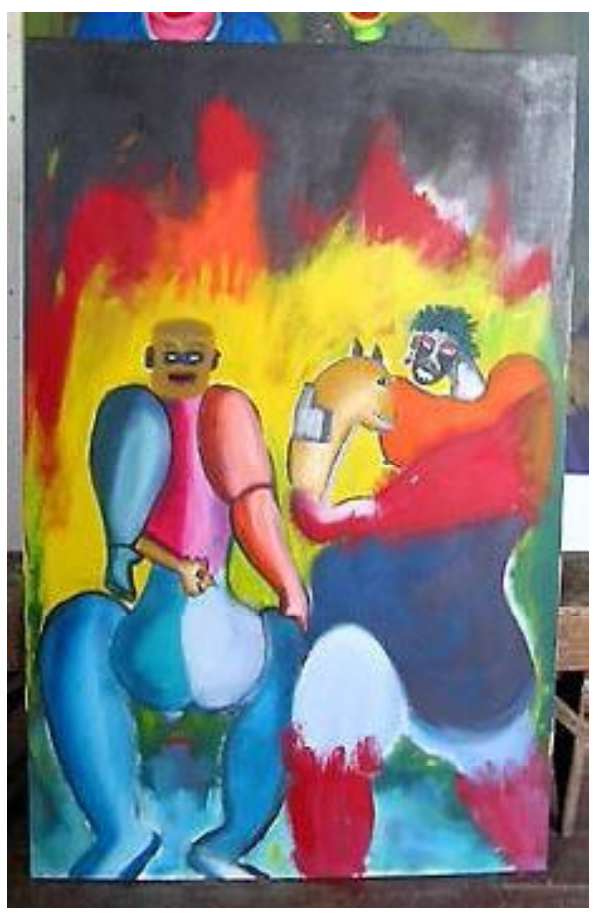

Na tela exposta, as formas volumosas das mulheres protagonistas de suas obras e os tons quentes evocam a sensualidade despertada pelo carnaval, regido pelas tentações da serpente e pelos encantos de Eva.

No conto de Oswaldo Osório, a descrição da personagem Rebindita - o nu feminino que se exibe para a fruição masculina - ressalta as reações que sua sensualidade desperta no narrador-personagem e o cotejo com a tela "Coca Cola é sabura", também de Tchalê Figueira, parece-me evocar o imaginário cultural desta mulher que se oferece para ser "saboreada", mas é, ao mesmo tempo, "desprezada" pelo mundo patriarcal:

Se a visses nua, se te queimasses no calor do seu corpo, não terias tanto desprezo [...]. Não é preciso dizer-te que ela dança a coladeira fera como nenhuma. [...] ao pôr-se nuínha: seios de virgem, rapaz, tesos e cónicos como açúcar de forma da Praia, da cor do açúcar mascavado, que chupei em ponto de rebuçado fervendo dentro de mim, ao sentir-lhes a consistência. $O$ ventre de meia-lua onde se encastoava ligeiro acidente que me passava quase despercebido, o umbigo, liso e a adelgaçar-se era também de mulher que nunca tinha engravidado. Vibrátil e de carícias de dedos de seda. Mínimo toque a enlanguesce. Dá-se entre gemidos, afagos e, se morde, fá-lo para desencadear novas torrentes de prazer (OSÓRIO, 2003, p. 121). 


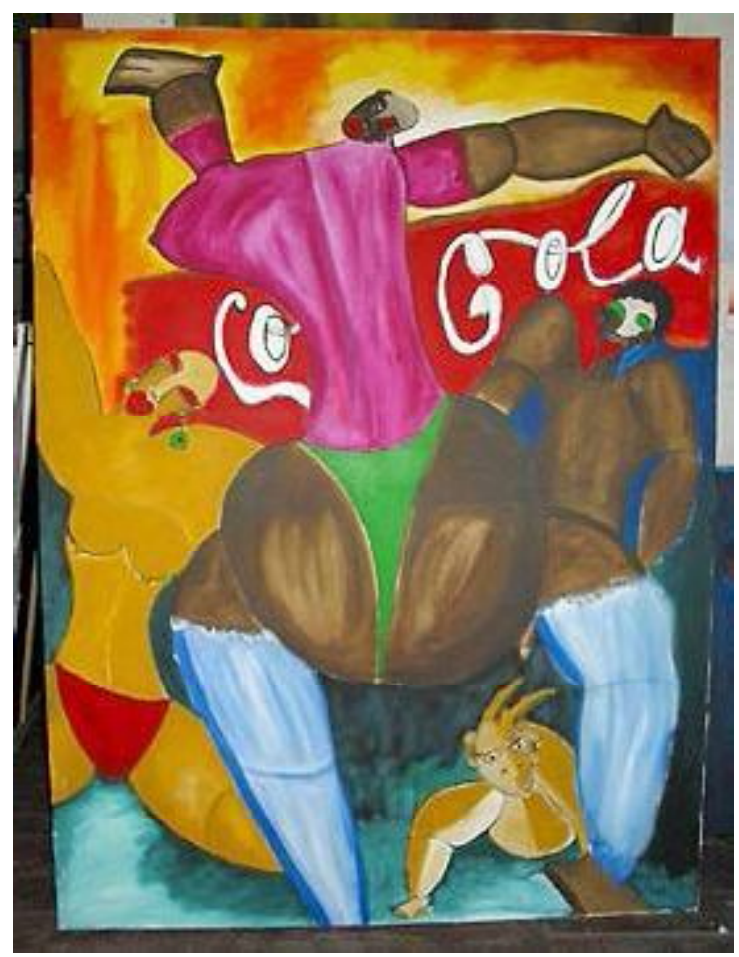

Essa mulher que se expõe, que se dá e propicia momentos de prazer terá um comportamento previsível para o amigo do personagemnarrador, que a encara sob preconceito: sua libido exuberante a conduzirá, fatalmente, à traição: "Procedeu como menina de vida que é. Mais tarde ou mais cedo havia de acontecer. Trazem-no no sangue, é como se fosse hereditário [...] é uma..." (OSÓRIO, 2003, p. 121). A premissa biológica determinista, utilizada para estigmatizar o gênero feminino enquanto submisso a uma perspectiva machista-positivista, define a mulher ora como um ser passivo destinado ao deleite, ora como ser ativo diabolizado e merecedor, por isso, do tratamento de baixo calão ("é uma..."), sugerido por omissão, nas reticências, pela personagem masculina.

Acrescenta Maria Lúcia Rocha-Coutinho (1994, p. 26) que o discurso biológico da "natureza feminina", o confinamento das mulheres à esfera doméstica e a maternidade como programa político dão suporte à ideologia falogocêntrica. Tomando de empréstimo, na próxima sala, telas de Kiki Lima, seja a Eva ou a bruxa de potência orgástica queimada entre os séculos XV e XVIII, seja a mulher santificada, "dona" (?) do lar, para Rocha-Coutinho (1994, p. 44), ambas seriam governadas, segundo aquela ideologia, pelo seu útero.
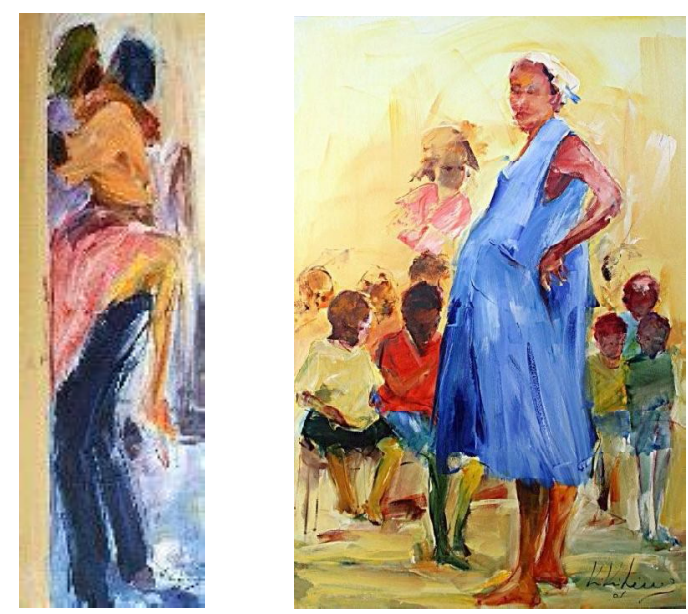
O fato de a Rebindita dançar a coladeira (ritmo cabo-verdiano extremamente sensual) com voluptuosidade de "fera" complementa o retrato daquela felina que, disfarçada de "coelhinha" num baile de Carnaval, é apresentada como objeto de desejo por um narradorpersonagem dado a "farras" e aos bailes do Miradouro e do Tolentino. $O$ observador masculino, implícito no conto de Oswaldo Osório, traça um retrato feminino da "tentação" que aquela mulher provoca no macho que a ela não se furtará, já que a sexualidade, nas sociedades patriarcais, é centrada no prazer do homem, o que gera representações do corpo feminino como "maleável, instrumental e descartável" (FUNCK, 2003, p. 476). Para Susana Bornéo Funck, uma

[...] análise feminista da literatura produzida por homens torna-se, assim, desde seu início, uma crítica da cultura sexual patriarcal [...], uma vez que a mulher é idealizada e que a construção cultural do desejo masculino traz embutida a noção de conquista e dominação do objeto (Ibidem).

Em contraponto a essa visão cultural androcêntrica, o poema de Vera Duarte intitulado "Os sinais", exposto na próxima sala da galeria, indiciará uma nova subjetividade ("outros sinais"), a feminina, que escolherá outras vias para marcar a sua historicidade. Sobre a rasura das argumentações positivistas e da história narrada pelas elites masculinas, esclarece Margareth Rago: "é possível dizer que as mulheres estão construindo uma linguagem nova, criando seus argumentos a partir de suas próprias premissas" (RAGO, 1998, p. 31). As marcas gravadas pela trajetória feminina, aqui, buscarão superar as diversas formas de escravatura (da sensualidade, da prostituição, do confinamento ao lar e ao casamento, da maternidade como fim político último), propondo uma resistência a um arcabouço que insiste em, de alguma forma, vitimizá-la:

Pelo tempo por que passei deixei gravados os meus sinais d'insurreição, revolta e rebeldia e d'alegria para lá da dor [...]

d'escrava amarrada ao tronco esperando a cruel chibata de pobre jovem impúbere abusada por todos os senhores de anónima operária exangue aos desmandos do patrão de triste esposa submissa obedecendo ao rude senhor [...] deixei gravados outros sinais de jornadas de luta de oitos de março do repto de Rimbaud do no woman no cry da fantástica solidariedade 
Pelo tempo por que passar

Deixarei gravados outros sinais sinais de fogo

de sangue

e de amores (DUARTE, Vera, 2001, p. 57-58).

Ao ultrapassar as cicatrizes da "dor" da "escrava amarrada ao tronco", da "jovem impúbere abusada por todos os senhores", "dos desmandos do patrão" à "anônima operária exangue" e da "triste esposa submissa" ao "rude senhor", por meio da "insurreição, revolta e rebeldia", esta mulher "deixa gravados outros sinais" que documentam a sua luta pela equidade de direitos. Como propõe Margareth Rago, o poema de Vera Duarte incluise numa linhagem que:

Mais do que a inclusão das mulheres no discurso histórico, trata[-se], então, de encontrar as categorias adequadas para conhecer os mundos femininos, para falar das práticas das mulheres no passado e no presente e para propor novas possíveis interpretações inimagináveis na ótica masculina (RAGO, 1998, p. 95).

Assim, a história contada no feminino tem recorrido à abordagem do cotidiano das mulheres, que permite o reencontro dos tempos desiguais e simultâneos no espaço do vivido e das resistências possíveis de fazer face à visão de uma história "miserabilista", na qual se sucediam "mulheres espancadas, enganadas, humilhadas, violentadas, subremuneradas, abandonadas, loucas e enfermas" (PERROT, 1987, Apud. SOIHET, 1998, p. 100). A hermenêutica do cotidiano das mulheres permitiu emergir o perfil da mulher rebelde, dando destaque a contradiscursos construídos no domínio do miúdo e do detalhe (RAGO, 1998, p. 23).

As telas de Kiki Lima expostas nesta sala da galeria, constantes do seu "Xikinha: Romance pintóde" (2007), em diálogo com o poema de Vera Duarte, unem verso e visual numa proposta de construção de melhores condições para as mulheres cabo-verdianas:

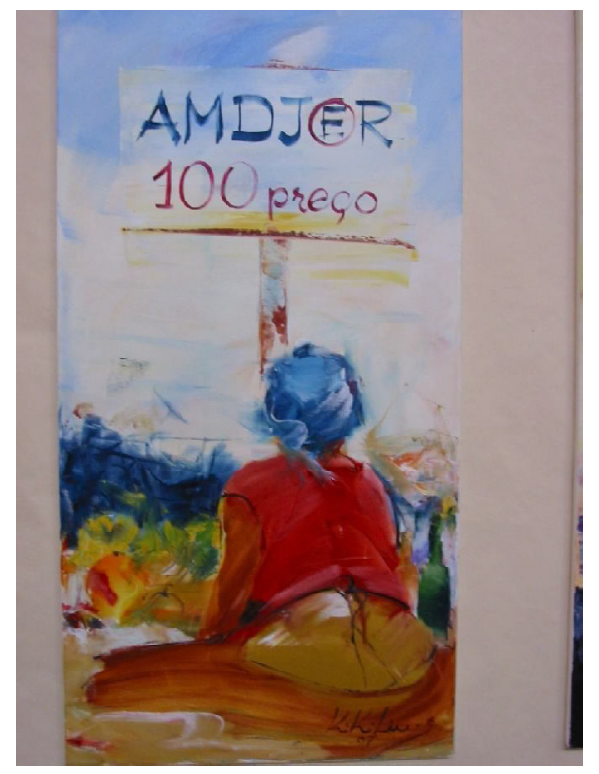




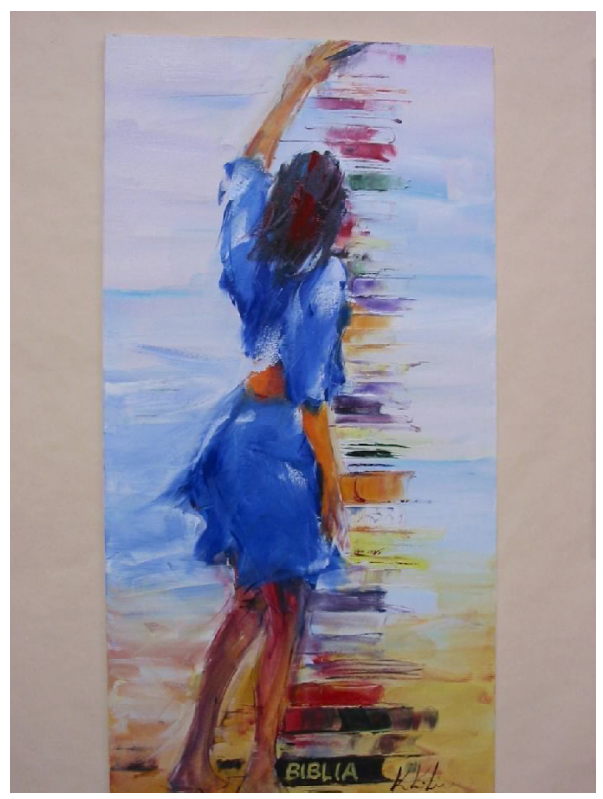

"M'sentá na luta pa um amdjer amdjor" (por uma mulher melhor) e "M'pegá na livre m'pasá por cima" (nos livros, passei por cima) são os versos-legenda das telas de um artista que prima pela "pintura de gênero", apresentando personagens do povo em atividades laborais. O cotidiano sobre o qual se debruça a arte de Kiki Lima, contudo, é quase que invariavelmente o feminino, retratando a mulher cabo-verdiana em tarefas informais de trabalho (série da cachupa) ou lazer (série das danças), em pinceladas que expressam o movimento da técnica, mas também a ação das figuras: um feminino em transformação.

Costumo afirmar que as mulheres, na obra de Kiki Lima, são representadas numa ótica feminina de focalização e valorização, como se o pintor se tornasse cúmplice de suas vozes, que contam uma trajetória de labuta diária e de construção do país por meio de um contradiscurso que emana do campo cotidiano do miúdo e do detalhe, como propõe Margareth Rago (1998, p. 23). Sinais de uma natureza outra, diversa do épico masculino dos grandes feitos, constroem a historicidade feminina em Cabo Verde, como exposto no poema de Vera Duarte e nas telas de Kiki Lima. Sinais inscritos numa perspectiva de "respeito", como ressalta Josênia Antunes Vieira (2005, p. 236), que o discurso masculino de opressão muitas vezes esquecia de focalizar. Observemos, na próxima sala da galeria, o texto de Fátima Bettencourt em interlocução com telas de Kiki Lima e Sandro Brito (Ilha do Sal, 1975):

Mulheres jovens maduras, idosas, cada uma o seu encanto, a sua força. [...]. Uma mulata explode na dança de um vestido curto amarelo gema de ovo, a saia esvoaça no compasso do ritmo, revela no saracoteio o corpo bonito sugerindo o que não mostra. Mulheres vendedeiras complementam e rentabilizam o suor do seu homem. As da terra e as do mar. [...] Em todas a mesma dignidade e a certeza de pertencerem a um chão que fez delas 'guerrilheiras' da vida de onde sacam a pulso a determinação e a vontade de vencer, mas também a alegria e a musicalidade de todos os gestos e a sabedoria secular que lá de longe se vem acumulando até hoje (BETTENCOURT, 2001, p. 236). 

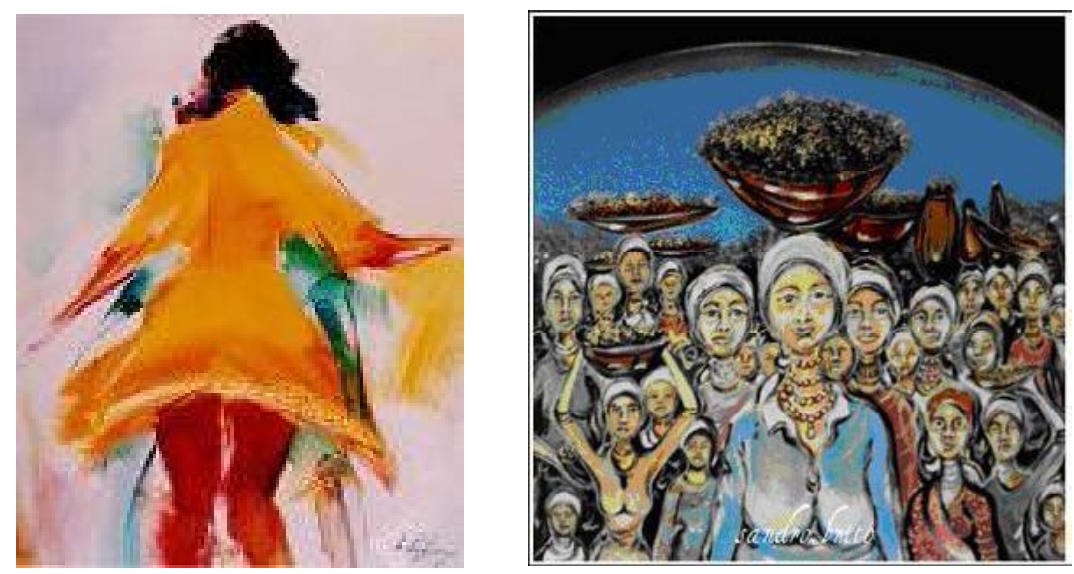

O vestido gema de ovo que, na pincelada de Kiki Lima e na pintura literária de Fátima Bettencourt, destaca em luminosidade o movimento e a energia da jovem cabo-verdiana associa-se ao movimento das vendedeiras, representadas em proliferação na tela de Sandro Brito ("Feira'), fundamentais, no seu cotidiano, à economia familiar e social. Une-as a "mesma dignidade", a "determinação" a construir, no seu chão, a sobrevivência dos filhos e o desenvolvimento do país: com "alegria", "musicalidade" e "sabedoria" ancestral. Imagens da cultura e da ação social, valorizadas pela literatura e pela pintura do cotidiano feminino.

Para encerrar a instalação, na última sala, sem muitos comentários, deixo ao leitor de imagens o diálogo de telas de Misá (ilha de Santiago, 1962) e de Kiki Lima com texto de Maria Margarida Mascarenhas, em que uma Vênus cabo-verdiana do pó (e não marítima) assume o protagonismo das cenas, "desafiando" e vencendo no seu voo até mesmo um dos elementos mais potentes da paisagem cabo-verdiana, o vento:

Conceição amava o deserto. Buscava sempre as achadas descampadas para brincar. O Mar nunca. Banhava-se no pó, sentia as pedras e brincava com as nuvens em permanente mutação ao sabor do vento.[...]

Quando as nuvens açuladas pelo vento doido cabriolavam no céu, projectando sombras velozes, Conceição corria desafiando as nuvens, desafiando o vento (MASCARENHAS, Maria Margarida, 1988, p. 14-15).
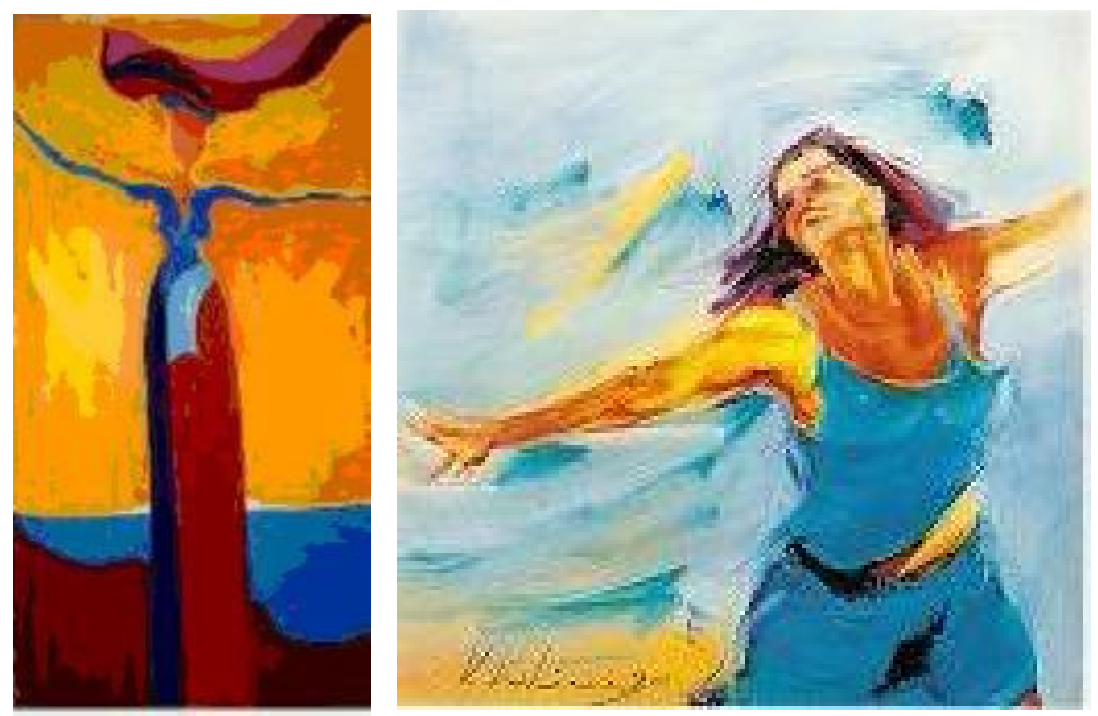
Ao sabor do vento, mimetizando-o no seu movimento, ou mesmo contra ele, se necessário, movem-se as mulheres cabo-verdianas representadas por Conceição do pó e da pedra, valorosas "guerrilheiras" construtoras de um Cabo Verde mais igualitário e melhor.

\section{REFERÊNCIAS BIBLIOGRÁFICAS}

ALMEIDA, José Evaristo d'. O escravo. Lisboa: ALAC, 1989. Prefácio de Manuel Veiga.

BENJAMIN, Walter. "A obra de arte na época de sua reprodutibilidade técnica". In: LIMA, Luiz Costa [org]. Teoria da cultura de massa, Rio de Janeiro: Sage, 1970, p. 207-238.

BERGER, John. Modos de ver. Rio de Janeiro, Rocco, 1999.

DIAS, Maria Odila Leite da Silva. Novas subjetividades na pesquisa histórica feminista: uma hermenêutica das diferenças. In: Estudos feministas. UFRJ/CIEC, 20 semestre, 1994, p. 373-382.

DUARTE, Vera. O arquipélago da paixão. Mindelo: Artiletra, 2001.

FORTES, Corsino. A cabeça calva de Deus. Lisboa: Publicações Dom Quixote, 2001.

GOMBRICH, Ernst H. Simbolic Images - Studies in the art of Renaissance II. New York: Phaidon Press, 1978.

GONÇALVES, Carlos Filipe. Kab Verd Band. Praia: Instituto do Arquivo Histórico Nacional, 2006.

LEAL, António da Costa et alii. Kiki Lima. Com ilustrações de Kiki Lima. Lisboa: Editorial Caminho, 2003.

LOPES, Baltasar. Chiquinho. S. Paulo: Ática, 1986.

LOPES, Manuel. O galo que cantou na baía. Lisboa: Edições Orion, 1959. Galo cantou na baía e outros contos. Porto: Edições 70, 1984.

LOUDE, Jean-Yves. Cabo Verde: notas atlânticas. Lisboa: Publicações Europa-América, 1999.

MANGUEL, Alberto. Lendo imagens. . Paulo: Companhia das Letras, 2001.

MARTINS, Vasco. Navegam os olhares com o vôo do pássaro. Praia: Instituto Caboverdiano do Livro, 1989.

MASCARENHAS, Maria Margarida. ...Levedando a ilha: contos. Linda-aVelha: ALAC, 1988.

MCDERMOTT, LeRoy. Self-Representation in Upper Paleolithic Female Figurines. http://cmsu2.cmsu.edu/ 1dm4683/index.htm. Acessado em 11/07/2010.

MITCHELL, Thomas (org). The language of images. Chicago: and London: Chicago UP, 1974.

SERRES. Michel. Atlas. Madri: Cátedra, 1994.

SOURIAU, Étienne. A correspondência das Artes. elementos de estética comparada. São Paulo: Cultrix, 1983.

VEIGA, Manuel. A propósito de "O primeiro romance cabo-verdiano". In: A sementeira. Lisboa: ALAC, 1994. P. 101-109.

WITCOMBE, Chris. Images of women In Ancient Art: Issues of Interpretation and Identity. Disponível em: http://www.arthistory.sbc.edu/ imageswomen. Acessado em 11/07/2010. 


\section{NOTAS}

1.Terminologia proposta por Malraux.

2. Em fala no Simpósio comemorativo dos 50 anos da revista Claridade, 1986.

3. Ripundá tchabéta, acelerar a percussão.

4. Mais tarde designada de Milo. 